\title{
RECYCLING OF CALCIUM-SILICATE MATERIAL AFTER WASTEWATER FILTRATION TO AGRICULTURE - SOIL CONDITION IMPACT
}

\author{
WYKORZYSTANIE ROLNICZE MATERIALÓW \\ WAPNIOWO-KRZEMIANOWYCH Z OCZYSZCZALNI ŚCIEKÓW \\ I ICH WPŁYW NA WŁAŚCIWOŚCI GLEBY
}

\begin{abstract}
Reactive filter materials aimed at phosphorus (P) recovery is a novel method for on-site wastewater treatment. Once the bed filter is no longer effective, the sorbent must be replaced and can then be recycled as a soil amendment to agriculture. This study investigated the short-term effects of such amendments in a field with a wheat crop in order to evaluate the risks and/or potential benefits of this disposal option. The developed product Polonite (manufactured from Opoka) was used as a model filter sorbent in the field trial. Rates corresponding to approximately 6 and 8 tons per hectare were applied. In the short-term, this amending did not affect soil physical and sorption properties. The rate of Polonite used here, as $\mathrm{P}$ source for wheat was irrelevant in this kind of soil. The usefulness of this disposal option of exhausted filter material is discussed.
\end{abstract}

Keywords: amendment, liming, phosphorus, Polonite, soil, sorption

Taking into account the scarcity of mineral phosphorus $(\mathrm{P})$ resources in the world, $\mathrm{P}$ recovery from agricultural and domestic sources is of great concern for future sustainable development [1]. The economic incentives for the implementation of $\mathrm{P}$ recovery are low today, but recovery is viable taking into account the environmental benefits [2]. A promising $\mathrm{P}$ capture and recycling option, at least for $\mathrm{P}$ flows in on-site systems in rural areas, is the reactive bed filter technology [3]. One of the promising materials used in such filters is Polonite, a commercial product first used in Sweden for on-site wastewater treatment and control of agricultural run-off. This calcium-silicate material can efficiently reduce the concentration of phosphorus $(\mathrm{P})$ and bacteria in effluent [3-5]. After a certain time, the material or sorbent is no longer efficient and it has to be replaced. It can then be

\footnotetext{
${ }^{1}$ Department of Land and Water Resources Engineering, KTH Royal Institute of Technology, Teknikringen 76, SE-100 44 Stockholm, Sweden, phone +46 8 7906350, fax +4684110775

${ }^{2}$ Department of Soil Science and Soil Protection, University of Agriculture in Krakow, al. A. Mickiewicza 21, 31-120 Kraków, Poland, phone +48 126624370

*Corresponding author: gunno@kth.se
} 
used as a soil amendment in agriculture, recycling $\mathrm{P}$ and other macro- and micronutrients to plants and replacing lime [6-8].

Recycling of P-saturated filter materials may help reduce the use of mineral $\mathrm{P}$ fertilisers, which has two main advantages. First, it would lower the depletion of limited and non-renewable phosphate ores; and second, it could decrease diffuse $\mathrm{P}$ pollution due to intensive fertilisation. In this regard, Ca-containing materials such as Polonite can help improve soil structure by aggregating soil colloids. In addition, it is known that liming improves the availability of nutrients such as $\mathrm{P}$ in acidic to neutral soils [9], which may also reduce the need for $\mathrm{P}$ fertilisation. Polonite has given similar effects to liming on acidic soils in pots [7] and in field experiments [8]. Such effects were also observed for a rather neutral agricultural soil, where Polonite amendments increased soil $\mathrm{pH}$ and $\mathrm{P}$ availability in a pot trial [6]. In those short-term experiments, the application of Polonite did not have any negative effects on soils and plants. However, the concentration of $\mathrm{P}$ in Polonite was rather low $(0.1 \div 0.2 \% \mathrm{P})$ and probably represented just a fair contribution to total plant uptake, behaving as a slow-release fertiliser. On the other hand, its liming effect efficiently improved $\mathrm{P}$ availability, which may be advantageous in P-rich soils. Other expected effects of Polonite application to agriculture as a porous calcium silicate can be increased prevention of fungal infection, as shown by Saigusa et al [10].

The use of reactive filter materials for wastewater treatment and $\mathrm{P}$ recovery is quite new and particularly their recycling to agriculture. The authorities in Sweden have questioned this recycling, as pathogenic bacteria and heavy metals can contaminate the material after contact with wastewater. However, the metal content in the filter material from a household treatment unit is reported to be very low [11]. Another aspect of concern that has been raised by environmental authorities is the negative changes in soil conditions and plant production that may appear as a result of filter media application. For these reasons, we recently started research to evaluate the suitability of recycling Polonite and other filter materials after household wastewater treatment as a soil amendment.

Our vision is that Polonite can be applied to agricultural land, giving a small contribution of plant-available $\mathrm{P}$, without disturbing soil conditions for crop production. This study investigated the effects of Polonite amendments on the chemical and physical properties of a typical wheat-cropping field soil. The $\mathrm{pH}$ of soil in such fields is generally between 7 and 8 . This kind of soil is more important in agriculture than the acid and P-poor soils we studied before and was therefore an important rationale for the study presented here.

\section{Experimental}

The viability of recycling Polonite after wastewater treatment was tested in a field trial that ran from October to August, covering the winter wheat cropping season, ie simulating real conditions at a farm. The site was chosen for its adequacy, availability of resources, monitoring, climatic conditions, accessibility and proximity to the city of Krakow, where the experimental work was carried out.

\section{The calcium-silicate material Polonite}

Polonite (trade mark Polonite ${ }^{\circledR}$ ) is a commercial product derived from opoka, a bedrock rich in silica (50\%) and calcium carbonate (45\%) formed from marine sediments 
[12]. Polonite was used for 28 months in a filter well that collected and treated the effluent from a septic tank receiving wastewater from a single household [3]. This is one of the first on-site, fully monitored installations in Sweden using Polonite compact filters. After use, the substratum was removed from the filter, air-dried and stored for a few months before being applied to the soil. After wastewater treatment, Polonite had $\mathrm{pH} 9.7$, total $\mathrm{P}$ concentration $1.5 \mathrm{~g} \mathrm{~kg}^{-1}$ and $\mathrm{Ca}$ and $\mathrm{Mg}$ concentration 176 and $5.2 \mathrm{~g} \mathrm{~kg}^{-1}$, respectively [8]. In the following, this used material is referred to as Polonite-ww.

\section{Field experiment}

The Polonite-ww was transported from Sweden to the experimental field station situated in Lazy, about $40 \mathrm{~km}$ east of Krakow, Poland $\left(20^{\circ} 30^{\prime} \mathrm{E}\right.$; $49^{\circ} 58^{\prime} \mathrm{N}$; altitude $320 \mathrm{~m}$ a s 1). This agricultural soil is classified as a Haplic Luvisol and consists of 54\% sand, $39 \%$ silt and $7 \%$ clay [13], with $\mathrm{C} / \mathrm{N}$ ratio 10.4 and $\mathrm{pH} 6.5$. An area of approximately $200 \mathrm{~m}^{2}(40 \mathrm{~m} \times 5 \mathrm{~m})$ was divided into 20 plots of $10 \mathrm{~m}^{2}$ each $(4 \mathrm{~m} \times 2.5 \mathrm{~m})$ with $50 \mathrm{~cm}$ spacing (Fig. 1). This area was uncultivated during the year preceding the experiment, but it was intensively used for cropping during the previous decade, which notably increased the concentration of nutrients in the soil, particularly the concentration of $\mathrm{P}$. Regular application of lime was used to maintain a $\mathrm{pH}$ between $6 \div 7$ in the topsoil, while the $\mathrm{pH}$ is lower in deeper horizons as a consequence of soil properties and parent material characteristics [14]. Each plot in the selected area received nitrogen $\left(30 \mathrm{~kg} \mathrm{~N} \mathrm{ha}{ }^{-1}\right)$ as $\mathrm{NH}_{4} \mathrm{NO}_{3}$ containing $34 \% \mathrm{~N}$ and potassium $\left(140 \mathrm{~kg} \mathrm{~K} \mathrm{ha}^{-1}\right)$ as $\mathrm{KCl}$ with $60 \% \mathrm{~K}_{2} \mathrm{O}$ on 1 October 2007. In addition, plots received one of five different treatments:
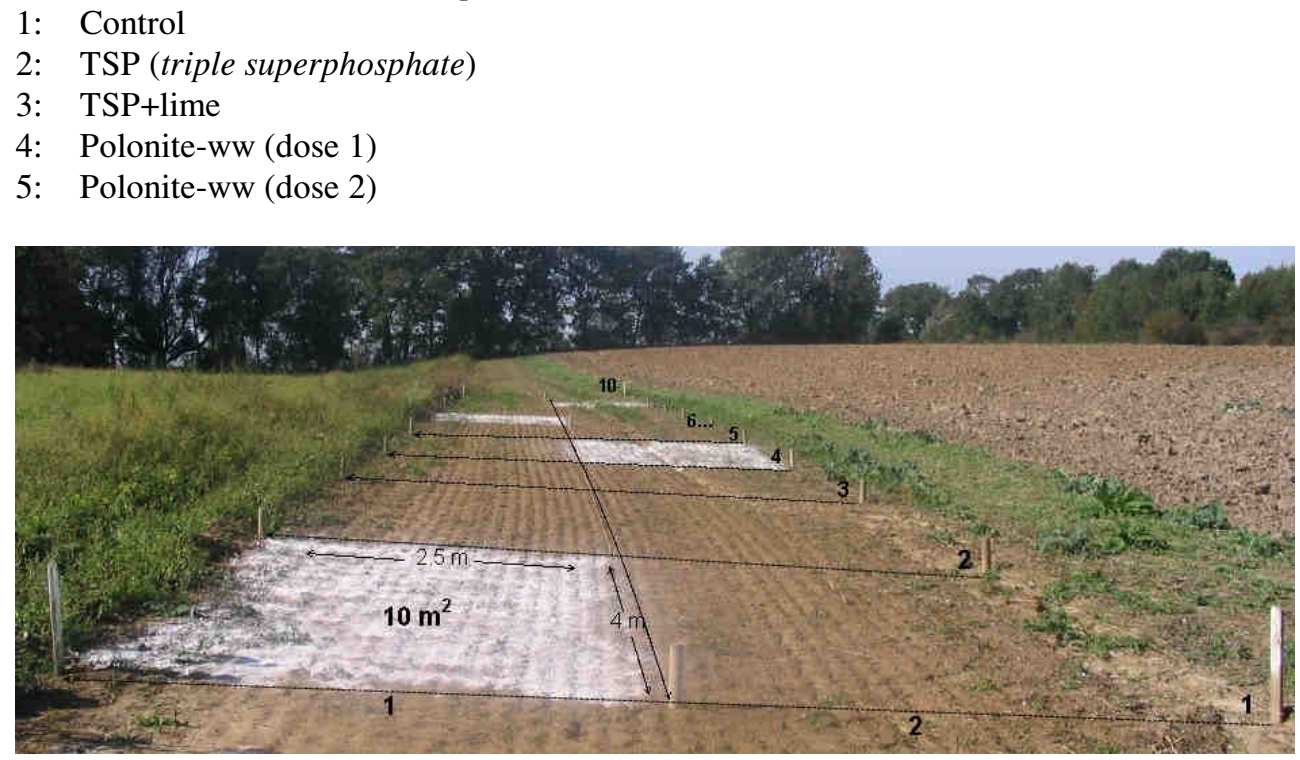

Fig. 1. Experimental field used for testing the filter sorbent Polonite as a soil amendment for a wheat crop in Lazy, Poland

Phosphorus was added as triple superphosphate (TSP) to reach a rate of $90 \mathrm{~kg} \mathrm{P} \mathrm{ha}^{-1}$. This is the common dose used in this field for intensive wheat cropping. Treatment 3 
incorporated lime containing $32 \% \mathrm{CaO}$ in addition to TSP fertilisation. Polonite-ww was added at rates based on previous experiences [6,8]. The filter material was crushed and sieved to a fraction $<2 \mathrm{~mm}$ in order to have a homogeneous distribution and enhance the release of $P$ and other elements to the soil solution. Doses 1 and 2 were 6 and $8 \mathrm{~kg}$ material per plot $\left(10 \mathrm{~m}^{2}\right.$ ), respectively (ie equivalent to $6 \mathrm{Mg}$ (ton) and $8 \mathrm{Mg}$ (ton) Polonite ha ${ }^{-1}$ ). The lower rate contained as much $\mathrm{Ca}$ as that of conventional liming used in this field. This rate was selected more on its lime content than its $\mathrm{P}$ content. Fertiliser compounds, Polonite-ww and lime were directly applied on the surface and then mixed into the upper soil layer $(0 \div 20 \mathrm{~cm})$ by ploughing. Each treatment was performed with four replicates.

Winter wheat (Triticum aestivum, L., cv. Mikula) was sown on 11 October 2007 at a seed rate of $200 \mathrm{~kg} \mathrm{ha}^{-1}$. The mean temperature in this field during the period 1987-2006 was $8.7^{\circ} \mathrm{C}$, with mean minimum and maximum temperatures of $-1.2^{\circ} \mathrm{C}$ and $18.7^{\circ} \mathrm{C}$, respectively, while the mean annual precipitation was $665.6 \mathrm{~mm}$. The average temperature during the experimental time-span (1 Oct $2007-8$ Aug 2008) was $8.8^{\circ} \mathrm{C}$ and the total precipitation $463 \mathrm{~mm}$. These data were obtained from the field research station in Łazy, which belongs to the Jagiellonian University in Krakow, Poland.

Harvesting took place on 8 August 2008. The wheat plants were cut manually at approximately $5 \mathrm{~cm}$ above the soil surface from a sub-area of $0.5 \mathrm{~m}^{2}$ centrally situated within each plot, and then dried and weighed (d.m. yield). The detailed data on plant yield related to fertilizing will be published elsewhere.

\section{Soil chemical analysis}

Soil samples were taken from the ploughed topsoil layer using sampling cylinders in eight different locations randomly distributed within the central part of each plot. The soil samples were dried at $55^{\circ} \mathrm{C}$ and milled for chemical analysis. Soil $\mathrm{pH}$ was measured in a 1:2.5 (w/v) soil:water suspension [15]. Plant-available forms were measured as ammonium lactate (AL)-extractable $\mathrm{P}$ and $\mathrm{K}$ in acetic acid [16] and as $\mathrm{CaCl}_{2}$-extractable $\mathrm{Mg}$ according to the Schachtschabel method [17]. The hydrolytic acidity (Hh) in soil was determined according to the Kappen method using $1 \mathrm{~mol} \mathrm{dm}{ }^{-3} \mathrm{CH}_{3} \mathrm{COONa}$ solution [15]. The base cation $\left(\mathrm{Ca}^{2+}, \mathrm{Mg}^{2+}, \mathrm{K}^{+}\right.$and $\left.\mathrm{Na}^{+}\right)$concentration was determined by atomic spectrometry using an AAS Solar M6 System after extraction with a $0.5 \mathrm{~mol} \mathrm{dm}^{-3} \mathrm{NH}_{4} \mathrm{Cl}$ solution. Total exchangeable base (TEB) cation concentration, cation exchange capacity (CEC) and base saturation (BS) percentage were then calculated as follows:

$$
\begin{gathered}
\text { TEB }=\left[\mathrm{Ca}^{2+}\right]+\left[\mathrm{Mg}^{2+}\right]+\left[\mathrm{K}^{+}\right]+\left[\mathrm{Na}^{+}\right] \\
\mathrm{CEC}=\mathrm{Hh}+\mathrm{TEB} \\
\mathrm{BS}(\%)=\frac{\mathrm{TEB}}{\mathrm{CEC}} \times 100
\end{gathered}
$$

\section{Soil physical analysis}

Soil solid phase particle density (SPD) was determined by the pycnometer method. The bulk density (BD) was measured in soil samples with undisturbed structure collected in $100 \mathrm{~cm}^{3}$ cylinders. In the same samples, water retention at field capacity (WFC), corresponding to a water potential of $-9.81 \mathrm{kPa}(\mathrm{pF}=2.0)$, was assessed using a porous plate inside a pressure chamber. Saturated hydraulic conductivity coefficient (Ks) was 
estimated according to the Wit method [15]. Total porosity (TP) was calculated according to equation:

$$
\mathrm{TP}=\frac{\mathrm{SPD}-\mathrm{BD}}{\mathrm{SPD}}
$$

\section{Statistical analysis}

All the results are given as the mean of four replicates (plots) and the standard error $(\mathrm{SE})$ indicates the variation between replicates $(n=4)$. All the results were analysed statistically using one-way analysis of variance (ANOVA) by Tukey's test at $\mathrm{p}<0.05$ with SPSS 16.0.

\section{Results and discussion}

\section{Plant production and soil chemical properties}

There was no significant difference in plant yield between treatments. Since the treatments mainly differed in $\mathrm{P}$ application, the results suggest that soil $\mathrm{P}$ was sufficient for crop demand, which may have been due to intensive fertilisation of this agricultural soil during previous years.

Soil $\mathrm{pH}$ was unaffected by any of the two rates of Polonite-ww applied to the soil (Table 1). The addition of extra lime did not influence soil $\mathrm{pH}$ either. The soil seemed to buffer the addition of lime and Polonite-ww extraordinarily within nearly neutral soil $\mathrm{pH}$ values. Lime has been added to this agricultural field in the past, but it seems obvious that it is not needed at present. Deeper soil horizons have much lower $\mathrm{pH}$ values, whereas liming over the years has successfully maintained an adequate $\mathrm{pH}$ in topsoil to maximise crop production. The results for soil $\mathrm{pH}$ contrast with previous work where Polonite added to a soil with similar properties significantly increased soil $\mathrm{pH}$ in a pot experiment [6]. In that experiment, Polonite samples were treated with artificial $\mathrm{P}$ solutions instead of wastewater and had a $\mathrm{pH}$ of 9.9 (instead of 9.7 for Polonite-ww), and some soil properties were different. The rate of added Polonite-ww in the present study was lower as it was mixed within the $0 \div 20 \mathrm{~cm}$ layer.

Table 1

Soil $\mathrm{pH}$ and available $\mathrm{P}, \mathrm{K}$ and $\mathrm{Mg}$ (mean $\pm \mathrm{SE}$ ) after harvest for the five different treatments

\begin{tabular}{|c|c|c|c|c|}
\hline Treatment & pH & Avail-P [mg kg ${ }^{-1}$ ] & Avail-K [mg kg ${ }^{-1}$ ] & Avail-Mg $\left[\mathrm{mg} \mathrm{kg}^{-1}\right]$ \\
\hline Control & $6.59 \pm 0.02$ & $91.85 \pm 5.86$ & $184.39 \pm 7.42$ & $130.74 \pm 7.53$ \\
\hline TSP & $6.69 \pm 0.02$ & $110.94 \pm 18.11$ & $208.15 \pm 36.47$ & $135.69 \pm 7.97$ \\
\hline TSP+Lime & $6.62 \pm 0.07$ & $97.98 \pm 7.46$ & $178.23 \pm 11.30$ & $128.11 \pm 3.25$ \\
\hline Polonite-ww1 & $6.67 \pm 0.04$ & $110.97 \pm 13.37$ & $194.07 \pm 26.35$ & $128.44 \pm 5.73$ \\
\hline Polonite-ww2 & $6.54 \pm 0.02$ & $87.92 \pm 4.28$ & $199.35 \pm 16.79$ & $127.78 \pm 1.98$ \\
\hline
\end{tabular}

Notation: TSP - triple superphosphate, Polonite - ww1, ww2 - dose 1 and 2 (6 kg and $8 \mathrm{~kg}$ material per plot, respectively)

Plant-available soil P, as extracted with ammonium lactate (AL) in acetic acid [16], was initially high already, suggesting that $\mathrm{P}$ fertilisation could probably be reduced in this field. However, farmers keep applying the same rate $\left(90 \mathrm{~kg} \mathrm{P} \mathrm{ha}^{-1}\right)$ in order to ensure maximum productivity. The availability of $\mathrm{P}$ in soil slightly increased with TSP and 
Polonite-ww1 treatments compared with the control treatment but not when extra Polonite (Polonite-ww2) or lime was added. This shows that dosage is important when using Polonite-ww as amendment and excessive dosage may have the opposite effect. These observations agree with findings from batch equilibrations using Polonite-ww showing a clear dependence on rate of amendment (Renman et al, on-going research). Both previous and present results suggest that depending on the concentration of sorbed $\mathrm{P}$ and $\mathrm{pH}$ of Polonite-ww, soil $\mathrm{P}$ status and soil $\mathrm{pH}$ and the ratio between the two, the substrate may behave either as a slow-release $\mathrm{P}$ source or as a $\mathrm{P}$ trap. Since soil $\mathrm{pH}$ in this luvisol is close to neutrality and the pool of available $\mathrm{P}$ is high, adding more $\mathrm{Ca}$ may lead to $\mathrm{P}$ immobilisation through precipitation reactions, thus restricting plant uptake.

Since wheat yield was similar for all treatments and the concentration of available $\mathrm{P}$ in soil was not significantly different, so the mass balance suggests that most $\mathrm{P}$ applied as TSP (90 kg P ha ${ }^{-1}$ ) was probably washed out by surface run-off or sub-surface leaching. This explanation is supported by the fact that heavy rain events took place just before the experiment started (September) and the precipitation was also intense during the first two months, thus increasing surface run-off and leaching. It is also known that depending on manufacturing method, TSP fertilisers can have small amounts of insoluble P [18]. The large proportion of soluble $\mathrm{P}$ may have an impact on the surrounding water bodies when not needed, ie when the pool of available soil $\mathrm{P}$ is large and neither plants nor soil can cope with extra $\mathrm{P}$ addition. These issues and the consequences of high $\mathrm{P}$ concentrations in water derived from agriculture have been widely studied and reported [19, 20]. The application of Polonite-ww amendments did not affect the availability of $\mathrm{K}$ and $\mathrm{Mg}$ (Table 1). This was expected, since all treatments received similar K fertilisation, which was apparently enough to meet plant demands. The naturally occurring $\mathrm{K}$ in Polonite may become available in the long term and may be relevant for soils with poor $\mathrm{K}$ reserves or crops with poor $\mathrm{K}$ fertilisation. The considerable amount of natural occurring $\mathrm{Mg}$ in Polonite is known to be rather insoluble and not available [21].

Soil characteristics after harvest for the five different treatments (mean $\pm \mathrm{SE}$ )

\begin{tabular}{|c|c|c|c|c|c|c|c|c|}
\hline \multirow{2}{*}{ Treatment } & Hh & {$\left[\mathrm{Ca}^{2+}\right]$} & {$\left[\mathrm{Mg}^{2+}\right]$} & {$\left[\mathbf{K}^{+}\right]$} & {$\left[\mathrm{Na}^{+}\right]$} & TEB & CEC & BS \\
\hline & \multicolumn{5}{|c|}{$[\operatorname{cmol}(+) / \mathbf{k g}]$} & \multicolumn{3}{|c|}{$[\%]$} \\
\hline Control & $3.00 \pm 0.13$ & $4.50 \pm 0.36$ & $1.27 \pm 0.03$ & $0.39 \pm 0.03$ & $0.10 \pm 0.01$ & $6.26 \pm 0.37$ & $9.26 \pm 0.27$ & $\begin{array}{r}67.45 \\
\pm 2.15 \\
\end{array}$ \\
\hline TSP & $3.11 \pm 0.25$ & $4.31 \pm 0.63$ & $1.30 \pm 0.06$ & $0.42 \pm 0.02$ & $0.10 \pm 0.01$ & $6.13 \pm 0.63$ & $9.24 \pm 0.40$ & $\begin{array}{r}65.89 \\
\pm 3.82\end{array}$ \\
\hline TSP+Lime & $2.89 \pm 0.12$ & $5.19 \pm 0.38$ & $1.35 \pm 0.06$ & $0.35 \pm 0.01$ & $0.10 \pm 0.01$ & $6.98 \pm 0.36$ & $9.87 \pm 0.46$ & $\begin{array}{r}70.68 \\
\pm 0.72\end{array}$ \\
\hline $\begin{array}{l}\text { Polonite- } \\
\text { ww1 }\end{array}$ & $3.11 \pm 0.09$ & $4.63 \pm 0.30$ & $1.30 \pm 0.05$ & $0.41 \pm 0.04$ & $0.09 \pm 0.00$ & $6.43 \pm 0.32$ & $9.54 \pm 0.27$ & $\begin{array}{r}67.31 \\
\pm 1.57 \\
\end{array}$ \\
\hline $\begin{array}{l}\text { Polonite- } \\
\text { ww2 }\end{array}$ & $3.07 \pm 0.25$ & $4.70 \pm 0.42$ & $1.39 \pm 0.09$ & $0.42 \pm 0.06$ & $0.10 \pm 0.01$ & $6.65 \pm 0.48$ & $9.67 \pm 0.20$ & $\begin{array}{r}68.58 \\
\pm 3.57 \\
\end{array}$ \\
\hline
\end{tabular}

Notation: Hh - Hydrolytic acidity, TEB - total exchangeable base, CEC - cation exchange capacity, BS - base saturation percentage of soil after harvest for the five different treatments

Soil sorption properties were not affected by any of the treatments with the exception of extra lime addition, which slightly increased TEB, CEC and BS (Table 2). TSP treatment showed a tendency to decrease TEB and CEC, while Polonite-ww tended to increase these. 
The exchangeable acidity $(\mathrm{Hh})$ remained around $3 \mathrm{cmol}(+) / \mathrm{kg}$ for all treatments. It is possible that the use of conventional ploughing for soil preparation at the beginning of the experiment tended to mix the amendments within deeper soil layers and the rather superficial sampling did not fully represent the whole volume of soil interacting with them. This and the fact that $\mathrm{Ca}$ is prone to leaching in sandy soils would explain the negligible effect of both Polonite-ww and lime on soil sorption properties. Similar Polonite-ww samples had a significant liming effect on an acid soil, significantly increasing the $\mathrm{Ca}$ content in soils amended with similar rates of the substrate to those used in this work [8].

\section{Soil physical properties}

The water content of this soil at field capacity was 35 vol.\% and the bulk density ranged from 1.51 to $1.55 \mathrm{Mg} \mathrm{m}^{-3}$ (Table 3). These two parameters, and therefore soil total porosity, were not affected by Polonite-ww amendments in this experiment. Thus, the application rates of Polonite-ww were within the range that did not affect soil structure. However, this may change in the long term after weathering of Polonite-ww. The high porosity and elevated content of silica in Polonite is expected to have an impact on some of these physical properties, but this will depend on soil type (soil texture and clay content) and to some extent on climate conditions.

Table 3

Physical properties of soil samples after harvest for the five different treatments (mean $\pm \mathrm{SE}$ )

\begin{tabular}{|c|c|c|c|c|}
\hline Treatment & WFC [\% v/v] & $\mathrm{BD}\left[\mathrm{Mg} \mathrm{m}^{-3}\right]$ & TP $[\% \quad \mathrm{v} / \mathrm{v}]$ & $\mathrm{Ks}\left[\mathrm{cm} \mathrm{d}^{-1}\right]$ \\
\hline Control & $0.34 \pm 0.01$ & $1.51 \pm 0.03$ & $0.62 \pm 0.03$ & $2.97 \pm 0.35$ \\
\hline TSP & $0.35 \pm 0.01$ & $1.55 \pm 0.03$ & $0.58 \pm 0.03$ & $2.21 \pm 0.28$ \\
\hline TSP+Lime & $0.35 \pm 0.00$ & $1.54 \pm 0.03$ & $0.60 \pm 0.03$ & $4.44 \pm 1.58$ \\
\hline Polonite-ww1 & $0.36 \pm 0.01$ & $1.53 \pm 0.02$ & $0.60 \pm 0.02$ & $3.24 \pm 0.56$ \\
\hline Polonite-ww2 & $0.35 \pm 0.00$ & $1.54 \pm 0.03$ & $0.59 \pm 0.03$ & $2.85 \pm 0.78$ \\
\hline
\end{tabular}

Notation: WFC - water field capacity, BD - bulk density, TP - total porosity, Ks - saturated hydraulic conductivity coefficient

The saturated hydraulic conductivity coefficient (Ks) was not significantly increased by Polonite-ww, but a slightly lower value was observed for TSP fertilisation, while lime addition tended to correct that negative effect on water conductivity (Table 3 ). This phenomenon is known to be associated with the ability of $\mathrm{Ca}$ to aggregate soil colloids [22]. The duration of the experiment may have been too short to let Polonite show similar properties. The negative effect of mineral fertilisation on soil infiltration has been found to be a relevant issue, affecting run-off $\mathrm{P}$ pollution and improving soil infiltration is one important mitigation measure to avoid this [23].

\section{Potential for Polonite and other filter media $\mathbf{P}$ capture and recycling}

According to the results of this study, the filter substrate (Polonite-ww) could be safely disposed of at rates of $6000 \div 8000 \mathrm{~kg} \mathrm{ha}^{-1}$ for one year (equivalent to the dosage used in this study) on wheat cropping fields. However, the present short-term study was unable to predict how accumulation of the substrate will affect soil properties and crops in the long run. Thus, the frequency of repeated spreading of filter material on the same field has to be further investigated. However, by simple extrapolation, Polonite-ww could be disposed of at 
rates of approximately $1000 \mathrm{~kg} \mathrm{ha}^{-1}$ per year for about 10 years (equivalent to the total amount added in this field trial). Thus, for a small community of 100 inhabitants served by Polonite filters, the amount produced (about 12,500 kg Polonite-ww per year) could be safely recycled to about 12.5 hectares. However, this area could probably be reduced, since higher rates are not expected to have harmful effects on soils and plants. In fact, the substrate would probably weather within the soil matrix and become part of it with time. Major constituents such as $\mathrm{Si}, \mathrm{Ca}$ and, to a lesser extent, $\mathrm{Al}$ and Fe oxides would then contribute to the soil composition.

The potential for $\mathrm{P}$ recycling is low, however, not because of low $\mathrm{P}$ sorption capacity of the material but rather because of the modest concentration of $\mathrm{P}$ in wastewater $\left(\sim 5 \div 10 \mathrm{mg} \mathrm{dm}^{-3}\right)$ [24]. This represents only about $0.5 \div 1 \mathrm{~kg} \mathrm{P} \mathrm{ha}^{-1}$ and year (for $1000 \mathrm{~kg}$ Polonite-ww ha ${ }^{-1}$ and year) based on total $\mathrm{P}$ sorbed to Polonite-ww, although this value could increase to $10 \mathrm{~kg} \mathrm{P} \mathrm{ha}^{-1}$ per year if higher rates are applied. In this way, it could also maintain an adequate soil $\mathrm{pH}$, as the liming effect of the substrate has great potential. For more acidic soils it could replace liming, as shown by [8]. For soils near neutrality the potential is lower. In the case of P-enriched soils, the fair $\mathrm{P}$ contribution and liming potential would probably provide sufficient $\mathrm{P}$ supply to maintain crop demands for some time. When soil P levels decrease or on P-depleted soils, additional P fertilisation would be necessary. These facts will be the case for all filter materials aimed for recycling $[25,26]$.

An interesting possibility would be to capture $\mathrm{P}$ in animal waste flows using reactive materials in filter beds. According to Rittman et al [24], these flows are not especially large, but the $\mathrm{P}$ concentration is high. For example, run-off from pig feedlots has peak $\mathrm{P}$ concentrations of $2400 \mathrm{mg} \mathrm{P} \mathrm{dm}$. The farmer could easily operate the filter unit and handle the filter material in cultivation, according to preliminary tests done in Sweden (Renman et al, unpubl.). Another use of Polonite or similar high P sorbing material [26, 27] could be to mitigate $\mathrm{P}$ losses from dairy slurry [cf. 28].

\section{Conclusions}

This preliminary study indicate that the filter sorbent Polonite used for household wastewater treatment (Polonite-ww) can be recycled to wheat cropping fields consisting of luvisol soils at rates of 6000 to $8000 \mathrm{~kg} \mathrm{ha}^{-1}$ per year, without negatively affecting crop yield and quality or soil chemical and physical properties. Depending on soil $\mathrm{P}$ status, additional $\mathrm{P}$ fertilisation may be needed, since the $\mathrm{P}$ contribution from Polonite-ww is low $\left(0.5 \div 1 \mathrm{~kg} \mathrm{P} \mathrm{ha}^{-1}\right.$ and year). This type of amendment might be of interest for P-enriched soils, reducing the need for $\mathrm{P}$ fertilisers and subsequent $\mathrm{P}$ pollution. The liming effect of Polonite-ww was not observed in this rather neutral agricultural soil and the addition of lime had no significant effect. This was probably due to the good condition and high $\mathrm{pH}$ of the soil. Further long-term studies on the particular luvisol and other agricultural soils and cropping systems are needed to fully evaluate the effects of using Polonite in agriculture.

\section{Acknowledgments}

We acknowledge the Swedish Institute for making this cooperation possible. Mr. Börje Öhrvall, Viksta, Sweden, owner of the house where Polonite was used in a filter well, kindly assisted with sampling of the material used in our experiment. The field station where the experiment was carried out belongs to the Jagiellonian University, Krakow, Poland. We 
gratefully acknowledge the expertise and contribution in the field of quality of yield of Dr. Robert Witkowicz, and the technical laboratory assistance of Magda Podgajny and Agnieszka Jozefowska.

\section{References}

[1] Schröder JJ, Smith AL, Cordell D, Rosemarin A. Chemosphere 2011;84:822-831. DOI:10.1016/j.chemosphere.2011.01.065.

[2] Molinos-Senante M, Hernández-Sancho F, Sala-Garrido R, Garrido-Baserba M. Ambio 2011;40:408-416. DOI: $10.1007 / \mathrm{s} 13280-010-001-9$.

[3] Renman A, Renman G. Chemosphere 2010;79:659-664. DOI: 10.1016/j.chemosphere.2010.02.035.

[4] Renman G, Kietlińska A, Cucarella Cabañas V. Treatment of phosphorus and bacteria by filter media in onsite wastewater disposal systems. Proc $2^{\text {nd }}$ Inter Symposium on Ecological Sanitation. Lubeck; 2004:573-576.

[5] Gustafsson JP, Renman A., Renman G, Poll K. Water Res. 2008;42:189-197. DOI: 10.1016/j.watres.2007.06.05.

[6] Cucarella V, Zaleski T, Mazurek R, Renman G. Polish J Environ Stud. 2007;16:817-822.

[7] Cucarella V, Zaleski T, Mazurek R, Renman G. Bioresource Technol. 2008;99:4308-4314. DOI:10.1016/j.biortech.2007.08.037.

[8] Cucarella V, Mazurek R, Zaleski T, Kopeć M, Renman G. Environ Pollut. 2009;157:2147-2152. DOI: 10.1016/j.envpol.2009.02.007.

[9] Haynes RJ. Plant Soil 1982;68:289-308.

[10] Saigusa M, Yamamoto A, Shibuya K. Plant Prod Sci. 2000;3:51-54.

[11] Renman A, Renman G, Gustafsson JP, Hylander LD. J Hazard Mat. 2008;166:734-739. DOI:10.1016/j.jhazmat.2008.11.127.

[12] Brogowski Z, Renman G. Polish J. Environ Stud. 2004;13:15-20.

[13] FAO-ISRIC-ISSS, World reference base for soil resources. World soil resources, Reports 84. Rome; FAO: 1998.

[14] Skiba S, Drewnik M. Resistance of luvisols from Wieliczka Foothills to chemical degradation. Zeszyty Naukowe UJ, Prace Geograficzne, Kraków, PL; 1995:100 (in Polish).

[15] Klute A. Methods of soil analysis. Agronomy Monograph 9. Madison, Wisconsin, USA: American Society of Agronomy; 1996.

[16] Egner H, Riehm H, Domingo WR. Kungl Lantbrukshögskolans Annaler 1960;26:199-215 (In German).

[17] Litynski T, Jurkowska H, Gorlach E. Analiza chemiczno-rolnicza. Przewodnik metodyczny do analizy gleby i nawozów. Warszawa: PWN; 1976 (in Polish).

[18] Johnston AE, Richards IR. J Agr Sci. 2003;140:267-274. DOI: 10.1017/S0021859603002971.

[19] McDowell RW, Sharpley AN. J Environ Qual. 2001;30:508-520. DOI:10.2134/jeq2001.302508x.

[20] Sharpley AN, McDowell RW, Kleinman P. J A Plant Soil. 2001;237:287-307.

[21] Hylander L, Kietlińska A, Renman G, Simán G. Biores Technol. 2006;97:914-921. DOI:10.1016/j.biortech.2005.04.026.

[22] Brady NC, Weil RR. The Nature and Properties of Soils. $11^{\text {th }}$ edition. Prentice Hall Int. Editions: New Jersey; 1996.

[23] Ulén B, Jakobsson C. Sci Total Environ. 2005;344:37-50. DOI:10.1016/j.scitotenv.2005.02.004.

[24] Rittman BE, Mayer B, Westerhoff P, Edwards M. Chemosphere. 2011;84:846-853. DOI:10.1016/j.chemosphere.2011.02.001.

[25] Cucarella V, Renman G. J Environ Qual. 2009;38:381-392. DOI:10.2134/jeq2008.0192.

[26] Jenssen PD, Krogstad T, Paruch M, Mælum T, Adam K, Arias CA, et al. Ecol Eng. 2010;36:1651-1659. DOI:10.1016/j.ecoleng.2010.07.004.

[27] Vohla C, Kõiv M, Bavor JH, Chazarenc F, Mander Ü. Ecol Eng. 2011;37:70-89. DOI: 10.1016/j.ecoleng.2009.08.003.

[28] Brennan RB, Fenton O, Rogers M, Healy MG. Soil Use Manage. 2011:27:238-246. DOI: 10.1111/j.14752743.2011.00326.x. 


\title{
WYKORZYSTANIE ROLNICZE POROWATYCH MATERIAŁÓW WAPNIOWO-KRZEMIANOWYCH Z OCZYSZCZALNI ŚCIEKÓW I ICH WPŁYW NA WŁAŚCIWOŚCI GLEBY
}

\author{
${ }^{2}$ Katedra Gleboznawstwa i Ochrony Gleb, Uniwersytet Rolniczy w Krakowie
}

\begin{abstract}
Abstrakt: Zastosowanie reaktywnych materiałów filtracyjnych jest nową metodą oczyszczania ścieków w miejscu ich powstawania i odzyskania $\mathrm{z}$ nich fosforu $(\mathrm{P})$. W celu zapewnienia efektywności oczyszczania ten materiał powinien być co pewien czas wymieniany. Ten zużyty, porowaty materiał może być wykorzystany w rolnictwie. W pracy przedstawiono wyniki badań nad zastosowaniem wapniowo-krzemianowego porowatego materiału w uprawie pszenicy. W badaniach polowych użyto Polonite - produktu handlowego wytworzonego z opoki, o wysokiej skuteczności oczyszczania ścieków bytowych z fosforu. W eksperymencie wykorzystano dwie dawki Polonitu 6 i $8 \mathrm{Mg} \cdot \mathrm{h}^{-1}$. Po jego zastosowaniu w krótkim okresie czasu nie stwierdzono wpływu na właściwości sorpcyjne i fizyczne gleby. Wpływ Polonitu na zawartość przyswajalnego fosforu w glebie był nieistotny. W pracy przedstawiono praktyczne znaczenie tej metody.
\end{abstract}

Słowa kluczowe: fosfor, wzbogacenie gleby, wapnowanie, Polonite, sorpcja 